Paula Ziviani

Doutora em Comunicação Social pela Universidade Federal de Minas Gerais (UFMG). Membro do grupo de pesquisa Centro de Convergência de Novas Mídias (CCNM/CNPq/ UFMG).

\section{Comunicação e cultura no campo dos estudos culturais}

Communication and culture in the field of cultural studies

\author{
Comunicación y la cultura \\ en el campo de los \\ estudios culturales
}




\section{RESUMO}

O objetivo deste texto é fazer uma breve retrospectiva sobre o conceito de cultura, apontando as principais contribuições dos autores dos Estudos Culturais e da Crítica Cultural para a compreensão da sociedade contemporânea e, consequentemente, de seus processos comunicativos. $O$ artigo apresenta uma perspectiva ampla sobre os Estudos Culturais e seus temas mais relevantes. Para tanto, explora-se as noções de cultura trabalhadas por Raymond Williams, Antonio Gramsci e Stuart Hall, assim como as questões que são trazidas à baila diante de tais conceitos. Ao final, procura-se localizar a perspectiva interacional da comunicação neste preâmbulo. Palavras-chave: Comunicação; Cultura; Estudos Culturais.

\section{ABSTRACT}

The aim of this paper is to make a brief review of the concept of culture, pointing out the main contributions of the authors of Cultural Studies and Cultural Critical to the understanding of contemporary society and, consequently, their communication processes. The article presents a broad over view about the Cultural Studies and its major themes. For that, the notions of culture worked by Raymond Williams, Antonio Gramsci and Stuart Hall are explored, as well as the matters that are brought to the fore by such concepts. At the end, we try to locate the interactional perspective of communication in this preamble.

KEYWORDS: COMMUNICATION; CULTURE; CULTURAL STUDIES.

\section{RESUMEN}

El objetivo de este trabajo es hacer una breve revisión del concepto de cultura, señalando las principales contribuciones de los autores de los Estudios Culturales y la Crítica Cultural para entender la sociedad contemporánea y, en consecuencia, sus procesos comunicativos. El artículo presenta una amplia perspectiva de los Estudios Culturales y de sus temas más relevantes. Para esto, se exploran las nociones de cultura trabajadas por Raymond Williams, Antonio Gramsci y Stuart Hall, así como las cuestiones que se señalan a la vanguardia de este tipo de conceptos. Al final, hemos tratado de localizar la perspectiva interaccional de la comunicación en este preámbulo.

Palabras-clave: Comunicación; Cultura; Estudios Culturales.

Submissão: 22-10-2014

Decisão editorial: 15-08-2017 


\section{Introdução}

O objetivo deste texto é fazer uma breve retrospectiva sobre o conceito de cultura, apontando as principais contribuições dos autores dos Estudos Culturais e da Crítica Cultural para a compreensão da sociedade contemporânea e, consequentemente, de seus processos comunicativos. O artigo apresenta uma perspectiva ampla sobre os Estudos Culturais e seus temas mais relevantes. Para tanto, explora-se as noções de cultura trabalhadas por Raymond Williams, Antonio Gramsci e Stuart Hall, assim como as questões que são trazidas à baila diante de tais conceitos. Ao final, procura-se localizar a perspectiva interacional da comunicação neste preâmbulo.

Um grupo heterogêneo de pensadores em fins do século XX e princípio do século XXI deu corpo ao chamado Estudos Culturais, ou seja, o desenvolvimento de uma teoria e de uma prática de análise que aborda a cultura a partir de um parâmetro ainda inédito. O novo terreno, segundo Hall (2003), foi marcado, num primeiro momento, pelas obras de Richard Hoggart (1973a; 1973b) e Raymond Williams (1969), e, posteriormente, pela produção de E. P. Thompson (1987a; 1987b; 1987c). Os Estudos Culturais originam-se na Inglaterra, nos anos 1950, e os primeiros encontros foram com a crítica literária e a história 
social. Tanto Hoggart quanto Williams "haviam procurado aplicar métodos literários de análise ao estudo de textos 'não-literários', assim como descrever, analisar e criticar a cultura popular contemporânea" (WILLIAMS, 2007, p. 421). Apesar da abordagem menos literária em relação aos outros dois pensadores, E. P. Thompson havia estudado também literatura inglesa e, assim como os demais, também fora influenciado por tal concepção.

Os Estudos Culturais se configuram a partir da conjugação da abordagem antropológica inglesa de cultura e do estruturalismo francês. O traço fundador alia uma concepção de cultura ligada ao cotidiano e à vida prática com uma perspectiva ideológica, associada a questões de poder e do campo de disputas.

Os intelectuais fundadores estavam ligados à Nova Esquerda britânica, à classe operária e à Educação de Jovens e Adultos. Como membros do Partido Comunista Britânico, a aproximação às ideias marxistas sempre existiu, mas, numa relação de empatia e confronto. A empatia se dá, dentre outros aspectos, pelo entendimento de que os trabalhadores vencerão a opressão a partir da luta de classes. No entanto, ao contrário da visão marxista mais ortodoxa, os autores dos Estudos Culturais entendem que essa luta se dará de outra forma que não a armada, e sim no plano das ideias. Nesse ponto, as contribuições de Antonio Gramsci (2001) têm importância fundamental para o campo, especialmente, no que se refere à sua reflexão sobre "hegemonia cultural", como veremos mais adiante. A obra de Gramsci, ainda que dentro do paradigma marxista, irá fornecer um conjunto de ideias que acabam por guiar os intelectuais britânicos ao deslocar a ênfase das estruturas e do econo- 
mismo, para a "importância das questões culturais e nacionais-populares e a função da sociedade civil no equilíbrio inconstante das relações entre as forças da sociedade" (HALL, 2003, p. 300).

Nesse aspecto, é possível afirmar que os Estudos Culturais se preocupam com o estudo da cultura, mas a partir de uma abordagem que privilegia uma espécie de intervenção política, como, por exemplo, os estudos da política cultural da diferença racial e sexual que tanto marcaram o campo. Trata-se de uma perspectiva que aborda o trabalho intelectual e teórico como uma prática política:

É uma iniciativa ou projeto sério, o que se inscreve no aspecto 'político' dos estudos culturais. Não que uma dada política se encontre inscrita, a priori, nos estudos culturais. No entanto, algo está em jogo nos estudos culturais de uma forma que, acho e espero, não é exatamente o caso em muitas outras importantes práticas e críticas intelectuais (HALL, 2003, p. 201).

Além da sua contribuição referente ao conceito de cultura, que será abordado a seguir, Williams foi um dos intelectuais que chamou a atenção para os meios de comunicação e o processo de transmissão de informação e mensagem. Segundo o autor (WILLIAMS, 1969), muitas vezes chamamos de comunicação apenas a transmissão, remessa num único sentido. Os meios de comunicação são como textos portadores de sentido e que revelam significados culturais. Williams ressalta a globalidade do processo comunicativo, ao firmar que a comunicação contempla transmissão, recepção e resposta, estes últimos dependentes de fatores outros que não processos meramente técnicos. 


\section{Conceito de cultura}

A complexidade do termo cultura é apontada por diferentes autores, mas, em especial por Raymond Williams, que chama a atenção para a historicidade do conceito, assim como estabelece suas relações com as mudanças sociais mais recentes. Em sua obra Palavras-chave (WILLIAMS, 2007, p. 123), ele afirma que "a complexidade, vale dizer, não está, afinal, na palavra, mas nos problemas que as variações do uso indicam de maneira significativa". Nessa perspectiva, o autor procura evidenciar o modo como a palavra cultura foi historicamente construída, ao destacar as principais transformações na apropriação do conceito ao longo do tempo, assim como a diferença de posição intelectual das diversas disciplinas, em vários países, que fizeram uso dessa vasta gama de significados.

O autor (WILLIAMS, 1977) ressalta algumas abordagens consideradas principais. A primeira delas faz menção à indissociabilidade entre cultura e natureza, ao cuidado com o crescimento natural da lavoura, da colheita e do processo de cultivo. A relação com o cultivo da natureza amplia-se para o cultivo do espírito, da construção do sujeito e do desenvolvimento humano. Dessa forma, numa outra abordagem histórica, a cultura passa a descrever um processo de desenvolvimento intelectual, espiritual e estético e associa-se ao conceito de civilização, que designa um estado consumado de vida social organizada. $\bigcirc$ autor aborda a noção "civilizar" no sentido de localizar os homens em uma determinada organização social. Tal perspectiva opera em consonância com dois sentidos primordiais: um estado que contrasta com a barbárie, e um estado realizado de desenvolvimento, que implica no avanço histórico. Este último, 
um projeto de construção do mundo, que tem como pano de fundo o espírito geral do lluminismo, com sua ênfase no autodesenvolvimento humano progressivo. Por conseguinte, a noção de civilização passa a ser sinônimo de cultura.

Diante da proposta de Williams (1977), qual seja a de observar o conceito de cultura dentro de um contexto mais amplo de desenvolvimento histórico, há uma ruptura com o conceito de civilização, e cultura passa a significar justamente aquilo que o progresso e a civilização são capazes de destruir. A análise que o autor faz se detém no estudo das transformações que a apreensão da "cultura" teve no pensamento da tradição inglesa entre os séculos XVIII e início do século $X X$. A perspectiva tem fundamento na comparação/ distinção entre a tradição iluminista francesa e a tradição romântica alemã. Williams (1977) revisou autores como Johann Gottfried von Herder e Jean-Jacques Rousseau para analisar tal comparação/distinção. Para ele, o embate entre cultura e civilização dá-se mais especificamente entre o lluminismo francês e o Romantismo, principalmente, alemão, com destaque para o filósofo Hérder. A perspectiva de Rousseau, iluminista francês, apresenta uma noção alternativa de cultura, considerada como um processo de desenvolvimento interior ou espiritual em oposição com o desenvolvimento exterior. A consequência principal foi associar cultura às artes imaginativas ou criadoras, ligadas à música, à literatura, à dança, à pintura, etc, isto é, às obras e às práticas decorrentes das atividades intelectuais e artísticas.

Nesse revés com o conceito de civilização, além de ser associada à arte, a cultura passou a significar também modos de vida e suas diferentes práticas 
sociais, "indicando um modo particular de vida, quer seja de um povo, um período, um grupo ou da humanidade em geral" (WILLIAMS, 2007, p. 121). Assim, o conceito de cultura perde a sua característica valorativa e passa a ressaltar a sua dimensão descritiva. Tal abordagem trabalha com a noção de cultura no plural, ao reconhecer em cada cultura a complexidade e a variabilidade de suas forças configurativas. Existe, portanto, a compreensão de um processo social fundamental que configura "estilos de vida" específicos e distintos, o que "constitui a origem efetiva do sentido social comparativo da cultura e, atualmente, de suas necessárias culturas plurais" (WILLIAMS, 1977, p. 28).

Diante do exposto, é possível destacar duas abordagens principais para o conceito de cultura na perspectiva de Williams. Para o autor (1977), numa primeira instância, o conceito de cultura teve uma função fundamental na definição de artes e de humanidades. Em uma segunda instância, sua função primordial e essencial foi na definição das ciências humanas e nas ciências sociais ${ }^{2}$, na medida em que 0 universalismo abstrato do conceito de cultura permitiu nomear o processo geral de configurações de "todos os estilos de vida", ou seja, uma teoria do processo social que produz estilos de vida específicos e diferentes. Nesse sentido, cultura está relacionada com as artes e a produção espiritual, no âmbito do simbólico e das representações, como também se relaciona com as diferentes práticas que ressignificam e dão

\footnotetext{
1 Segundo Williams (1977), a perspectiva da cultura no plural foi desenvolvida primeiramente por Johann von Herder, em sua obra Ideias para uma Filosofia da História da Humanidade.

2 A concepção pluralista foi de primordial importância para a evolução da antropologia, que continuou designando cultura como um modo de vida global (WILLIAMS, 2007).
} 
sentido às questões do simbólico e das representações. A cultura é um tipo de vivência que provê de sentido o modo como a sociedade organiza a sua vida e faz dela um todo coerente e inteligível.

Segundo Williams (1969, p. 18), "a evolução na palavra cultura dá testemunho de numerosas reações, importantes e continuadas, a essas alterações de vida social, econômica e política e pode ser encarada, em si mesma como um especial tipo de roteiro, que permite explorar a natureza dessas mesmas alterações". Para o autor, tais transformações no uso da palavra evidenciam os novos tipos de relações pessoais e sociais que vinham se constituindo ao longo do processo de desenvolvimento histórico. Nesse aspecto, Williams observa que depois de determinado período, a palavra cultura, que antes era usada em dois sentidos primordiais - a ideia de comportamento refinado e ligada às artes -, os debates sobre a questão passaram a preocupar-se com as relações entre cultura e sociedade. Tal perspectiva passou a questionar a cultura como sendo algo exclusivo de um grupo seleto, próprio de uma pequena minoria, a saber, a classe dominante; assim como a redução da cultura aos seus artefatos e produtos.

Num contexto de expansão e da emergência de uma sociedade das mídias, a preocupação de Williams (1969; 1977) vai girar em torno do que o autor entende por cultura popular e das formas de combater-se a dominação cultural. A perspectiva dele procura não fazer distinção entre alta cultura e baixa cultura ou cultura de massa, e sim refletir sobre os sistemas simbólicos ou de significação que estão por trás dessas questões. Ao construir um histórico do conceito de cultura, o autor defende a ideia de que a 
cultura ordinária ou cotidiana (da vida comum) pode ser vista como um modo de vida em pé de igualdade com o mundo das artes, da música e da literatura. Dessa forma, a cultura passa a ser entendida como algo da produção de sentido e significados, o que coloca a comunicação na centralidade do processo como elemento importante para o desenvolvimento de significações e valores.

Na visão do autor (WILLIAMS, 1969), existe uma cultura comum, isto é, a cultura de todos, sem distinção entre alta e baixa. Para ele a cultura é de todos, é algo comum a toda a sociedade, mas não é igual para todos. A possibilidade de existência da cultura comum só é possível num contexto de acesso igual às condições materiais e do processo democrático em sua plenitude. Ela pressupõe a igualdade do ser ao negar as duas afirmações históricas principais: cultura como algo privilegiado de poucos (classe burguesa e dominante); e cultura como herança de uma nova classe que emerge (no caso, a classe trabalhadora e proletariada), que traz em seu discurso a libertação da cultura dominante. Tal polaridade evidencia a luta de classes entre a burguesia e os trabalhadores. No entanto, para o autor, essa divisão é insustentável, uma vez que tanto os valores burgueses quanto os populares são constantemente reformulados e ressignificados ao longo do curso da história. A relação é complexa e dialética. Inclusive, no contexto da sociedade de massas e do advento das novas tecnologias de informação e comunicação, é praticamente inviável pensar nessa distinção, já que o trabalho imaginativo da cultura dita burguesa, as obras de arte, está cada vez mais difundido entre a "massa". Essa difusão se faz tanto pelo acesso a um maior número de informação 
e de conteúdo possibilitado pelas tecnologias, quanto pela a ampliação e democratização do sistema de educação, conforme ressaltado por Williams em sua argumentação sobre a cultura de massa.

As diferentes conformações dos sentidos da palavra "cultura" demonstram, em cada contexto histórico, o desenvolvimento de um tipo de pensamento e os seus propósitos sociais. A partir da perspectiva gramsciana de "hegemonia", Williams (1977) constrói seu argumento de que a cultura desempenha papel crucial no funcionamento e na manutenção do sistema. Os sistemas de dominação se dão, não apenas pelo poder e pela propriedade e sim, inevitavelmente, pela cultura do vivido e os modos de viver, ambos decorrentes da reprodução de uma ordem social profundamente arraigada. Os embates e acordos em torno da construção social têm na cultura elemento fundamental, uma vez que numa sociedade baseada na dominação, as disputas sociais são permanentes e apresentam as contradições que estruturam esse modo de vida. Para Williams (Ibidem, p. 111), "a 'hegemonia' vai além da 'cultura', (...), em sua insistência em relacionar 'todo o processo social' como distribuições específicas de poder e influência". Para o autor, hegemonia

É todo um conjunto de práticas e expectativas, sobre a totalidade da vida: nossos sentidos e distribuição de energia, nossa percepção de nós mesmos e nosso mundo. É um sistema vivido de significados e valores - constitutivo e constituidor - que, ao serem experimentados como práticas, parecem confirmar-se reciprocamente. Constitui assim um senso da realidade para a maioria das pessoas na sociedade, um senso de realidade absoluta, porque experimentada, e além da qual é muito difícil para a maioria dos membros da 
sociedade movimentar-se, na maioria das áreas de sua vida. Em outras palavras, é no sentido mais forte uma "cultura", mas uma cultura que tem também de ser considerada como o domínio e subordinação vividos de determinadas classes (Ibidem, p. 113).

A falta de distinção entre alta e baixa não significa dizer que as disputas em torno da cultura somem, nem tampouco a questão da existência das classes sociais. A proposta é de um estudo da cultura, isto é, dos significados e valores que organizam a vida comum, mas atenta às estruturas de poder. A partir da compreensão das formações culturais e do que estrutura os modos de vida, é possível descrever e interpretar a sociedade que acaba por conformar tais formas culturais e modos de vida. Toda cultura dominante contém em si o residual e o emergente, uma vez que "nenhuma ordem social dominante, nunca na realidade, inclui ou esgota toda a prática humana, toda a energia humana e toda a intenção humana" (Ibidem, p. 128). É nesse sentido que o autor irá afirmar que a hegemonia, a relação de supremacia entre grupos sociais (domínio e subordinação), não é universalizante e totalitária. Ao contrário, é sempre processual, algo que necessita de renovação e recriação contínua justamente pelo fato de que também sofre resistência contínua. Resistência decorrente de uma relação de complexidade que envolve uma série de confrontos e negociações, jogos de consenso e dissenso, estratégias de argumentação e persuasão, a saber, uma "contra-hegemonia" ou "hegemonia alternativa," nos próprios dizeres de Williams (1977). Nesse aspecto, a hegemonia está ao alcance tanto das classes dominantes quanto das subalternas. 


\section{Os Estudos Culturais e a Crítica Cultural}

Uma das principais marcas dos Estudos Culturais em relação às outras abordagens que tomam como objeto de estudo a cultura, é a não distinção entre alta e baixa cultura, conforme especificado na teoria da cultura de Williams $(1969 ; 1977)$. Diferentemente da Teoria Crítica ou da Crítica Cultural, por exemplo, em que o filósofo Theodor Adorno é o principal interlocutor, os Estudos Culturais vão enfatizar, não uma sociedade dominada e alienada, e sim a dimensão do conflito e da disputa entre classes e setores diferenciados no seio da cultura. Trata-se de uma ruptura ao propor-se estudar não apenas a alta cultura e a perspectiva da cultura ligada exclusivamente às artes, mas, trata-se de compreendê-la como um campo de luta em torno da significação social.

Em oposição à Teoria Crítica, a abordagem dos Estudos Culturais opera com base na perspectiva de que a sociedade não é harmônica, formada por uma massa única e absorta, e sim de que nela está entranhada a dimensão do conflito, do processo de disputa e de luta social política. Dessa forma, em contraposição à concepção adorniana, os pensadores dos Estudos Culturais, veem na cultura a possibilidade de afirmação de identidade e um campo privilegiado de disputas simbólicas. A perspectiva de Adorno aborda a cultura única e exclusivamente como possibilidade de negação e crítica da sociedade. Para o autor da Teoria Crítica, a cultura associa-se, essencialmente, às obras que advém de uma elevação do espírito e ligadas à arte; e na medida em que a cultura (a arte) se aproxima das relações econômicas e do mercado ela perde a sua capacidade de ser crítica, ocorre uma "castração da cultura", que 
se converte em "bens culturais" (ADORNO, 1971, p. 81). Segundo o autor, as dinâmicas de mercantilização da cultura acabam por impedir a formação de indivíduos autônomos, independentes e capazes de julgar e decidir conscientemente.

Ainda no contraponto entre a perspectiva da Crítica Cultural e dos Estudos Culturais, é interessante observar que os pensadores da teoria da cultura trouxeram para o centro da reflexão justamente os produtos midiáticos, advindos da televisão e da publicidade, ao concebê-los como cultura assim como as obras resultantes das capacidades imaginativas e criativas, isto é, as obras de artes. Para Adorno (1971), a cultura midiática não passa de um produto da indústria cultural, fruto de um processo de mercantilização e padronização da cultura.

Em sua proposta de estudar a sociedade como um todo e o projeto de dominação que marca o contexto da sociedade industrial, o referencial teórico principal da Teoria Crítica conjuga duas correntes principais, o marxismo e a psicanálise. Já no caso dos Estudos Culturais, Hall (2003, p. 201) afirma que:

Em nenhum momento os estudos culturais e o marxismo se encaixaram perfeitamente, em termos teóricos. Desde o início (...), já pairava no ar a sempre pertinente questão das grandes insuficiências, teóricas e políticas, dos silêncios retumbantes, das grandes evasões do marxismo - as coisas de que Marx não falava nem parecia compreender, que eram nosso objeto privilegiado de estudo: cultura, ideologia, linguagem e simbólico.

O marxismo adorniano defende que a lógica cultural do capitalismo expressa o tipo de dominação presente nas sociedades ocidentais do contexto industrial. A teoria social de Adorno (ADORNO e 
HORKHEIMER, 1985; 1999) diagnostifica a perda da subjetividade autônoma por meio da crítica a três processos considerados por ele primordiais e sintomáticos: o desenvolvimento tecnológico da sociedade, que favoreceu o enriquecimento e a melhoria da qualidade de vida; o positivismo excessivo da ciência, que acabou por domestificar o pensamento; e por fim, a estética e a cultura, que, na visão do autor, perderam sua capacidade crítica e reflexiva, quando passaram a operar de forma subverniente à lógica do capitalismo.

Já na concepção de Hall (2003), para os Estudos Culturais havia certo reducionismo e economicismo na teoria marxista ao analisar a sociedade e seus conflitos a partir da luta de classes e do ponto de vista exclusivo do capital, o que, no entendimento dos teóricos da cultura, impedia que se abordasse com seriedade as questões culturais (HALL; CHEN, 2003). Na visão de Adorno (1971), a "massa" era controlada por uma cultura dominante, que tinha função de tolher e alienar a população. Contudo, Hall (2003, p. 253-254) ao falar da complexidade do conceito de cultura popular, afirma não acreditar que exista uma grande massa de "'tolos culturais' que não sabem que estão sendo nutridos por um tipo atualizado de ópio do povo". Em sua visão, não existe nada mais anti-socialista do que imaginar o "povo como uma força mínima e puramente passiva".

O intelectual caribenho defenderá que operar de acordo com essa lógica significa imaginar a cultura popular ou da classe trabalhadora, como prefere chamar em alguns momentos, ora como autêntica e autônoma, situada fora do campo de forças das relações de poder e de dominação cultural; ora como 
algo isolado, encapsulado. Tal perspectiva não leva em consideração a "dialética da luta cultural" (HALL, 2003, p. 254-255), em que as indústrias culturais têm sim o poder de "retrabalhar e remodelar constantemente aquilo que representam; e, pela repetição e seleção, impor e implantar tais definições de nós mesmos de forma a ajustá-las mais facilmente às descrições da cultura dominante ou preferencial". Contudo, "essas definições não têm o poder de encampar nossas mentes; elas não atuam sobre nós como se fôssemos uma tela em branco". Em sua visão, elas retrabalham e influenciam as percepções da classe dominada, mas porque a cultura popular não é algo isolado. Existe sim uma relação de interação, de luta contínua, apesar de ser sempre irregular e desigual. Contudo, haverá sempre "pontos de resistência e também momentos de superação". E é justamente essa dialética que transforma o "campo da cultura em uma espécie de batalha permanente".

Nesse sentido, podemos listar alguns dos traços fundamentais que diferenciam a abordagem da Teoria Crítica da abordagem dos Estudos Culturais. $O$ primeiro deles consiste no fato de que para a Teoria Crítica a sociedade é dominada e submetida por completo ao capitalismo e ao poder da mídia. Em contraposição, conforme já mencionamos, para os Estudos Culturais a sociedade é conflitiva, permeada de lutas e disputas da hegemonia por classes e blocos diferenciados. Isso significa dizer que os Estudos Culturais reconhecem que existe a dominação, no entanto, segundo a perspectiva de hegemonia cultural tão cara ao campo, esta dominação existe como processo, algo constantemente mutável e não dado ou impermeável. Portanto, há uma quebra de 
parâmetro da cultura de massa como um todo homogêneo, para o qual o público receptor dos meios de comunicação de massa é visto como passivo, inerte, literalmente massificado e semelhante em todas as suas concretizações. O que não quer dizer que eles não reconheçam as intencionalidades de dominação por parte da indústria cultural. Contudo, tal dominação pode ou não existir, uma vez que existem outros elementos de intervenção que farão com que tais intencionalidades se realizem ou não.

Diferentemente da Teoria Crítica, há nos Estudos Culturais uma relativização do poder dos emissores no processo de comunicação. O que não significa subestimar sua capacidade de dominação da população, em especial dos trabalhadores. Os meios de comunicação, assim como a indústria cultural, podem sim ser um elemento unificador da ideologia dominante, um setor específico da produção capitalista que irá englobar toda uma produção simbólica, cujo objetivo é exercer o mesmo controle social que os trabalhadores sofrem no chão de fábrica. No caso, o sujeito passível deste controle social não possui condições nem de reflexão nem de resistência. Porém, para os Estudos Culturais este poder é relativizado a partir do acionamento do modelo gramsciniano de hegemonia e contra-hegemonia. A relativização não se dá no sentido das polaridades, onde um pêndulo, numa das pontas, irá apontar um sujeito engajado e revolucionário e, na outra extremidade, a própria nulidade deste sujeito, que se apresenta alienado, manipulado, dominado. Trata-se de um movimento dialético, a "dialética da luta cultural", numa relação de interação, uma dinâmica em que o próprio jogo dos opostos irá revelar as especificidades da consti- 
tuição de uma determinada sociedade, suas formas históricas específicas, portanto, contextualizadas, que nos permitem entender como os meios atuam.

Assim, a dominação não se dá pelo poder coercitivo de uma classe sobre a outra. Na concepção dos autores dos Estudos Culturais, a hegemonia é um jogo jogado entre as diferentes classes, a saber, a dominante e a subordinada, um jogo de concessões e conquistas (GRAMSCl, 2001). A hegemonia é dinâmica, onde se pressupõe compromissos e renúncias por parte do grupo que se pretende hegemônico; onde as demandas mínimas dos subalternos são consideradas, num jogo de sacrifício e deleite, cujo propósito é preservar o instável equilíbrio de forças. As classes subordinadas, a partir da perspectiva de hegemonia cultural desenvolvida por Gramsci, preparam-se, intelectual e politicamente, para "jogar o jogo da hegemonia" com as classes dominantes, onde nem a vitória nem tão pouco a derrota são definitivas. Há uma instrumentalização do saber conquistado, um domínio por parte dos subordinados das técnicas utilizadas pela classe dominante, em prol de uma intervenção na esfera político-social. Isto é, segundo Gramsci (2001, p. 15), todo grupo social, cria para si "uma ou mais camadas de intelectuais que lhe dão homogeneidade e consciência da própria função". Cada nova classe cria para si seus "intelectuais orgânicos" (lbidem), que repassam os conhecimentos, conscientizam as pessoas para o exercício de suas funções, onde os subalternos (um sujeito ativo, diferentemente da Teoria Crítica) tanto se submetem quanto criam resistências às visões das classes dominantes. Dessa forma, a hegemonia cultural consiste num espaço de conflitos e lutas constantes dos diferentes blocos so- 
ciais, que buscam consenso em meio à contradição inerente ao universo discursivo e comunicacional.

A concepção de cultura da Crítica Cultural se aproxima mais de uma leitura crítica da sociedade, do que de processos referentes ao mundo simbólico. Para Adorno (ADORNO e HORKHEIMER, 1985), a cultura da indústria cultural é fonte de controle social e, para os Estudos Culturais, a cultura é um campo de luta em torno de um sistema de significação social e da construção da identidade cultural e social de diferentes grupos. Diferentemente da concepção de Adorno e da Crítica Cultural, o sujeito não é ausente. Existe um todo social articulado (em interação), que se compõem de formas conflituosas e desiguais. $\mathrm{Na}$ visão dos Estudos Culturais, é possível identificar uma estrutura ideológica nas práticas culturais, mas, sempre relacionada às questões de poder e ao campo de forças em interação. Dessa forma, a questão cultural faz-se tão importante quanto o campo econômico e o político, na medida em que é no campo cultural que os debates ideológicos são travados, é nele em que ocorrem tanto a manutenção dos valores quanto à sua modificação.

\section{A contribuição dos Estudos Culturais para o campo da comunicação}

A cultura é vista pelos teóricos dos Estudos Culturais como o lugar do tensionamento, dos conflitos e das lutas que atravessam a experiência, como já mencionamos. Trata-se de uma constante politização da cultura, como sendo o lugar privilegiado para fazer-se uma leitura da sociedade e de suas relações. A análise dessas relações dá-se, entre outros pontos, a partir da investigação dos produtos culturais, 
tidos como textos que nos convocam a posicionamentos, na medida em que são sempre portadores de significado e sentido. Tais processos se exprimem especialmente no campo da comunicação, que tem assumido uma postura de mediadora social na contemporaneidade. A comunicação dar-se-á justamente na interação entre os textos que nos convocam e o posicionamento que tomamos. A contribuição dos Estudos Culturais para o campo da comunicação refere-se, essencialmente, à ênfase especial à cultura midiática e à inclusão das produções de massa no contexto da cultura. Hall (2003) leva em consideração que a comunicação se dá com base numa construção social, nas relações de poder e de pertencimento. Portanto, as mediações e interações sociais são decisivas para determinar como se realiza o processo comunicacional em cada contexto e sociedade.

Segundo Gramsci (2001, p. 78), "a imprensa ${ }^{3}$ é a parte mais dinâmica da estrutura ideológica, (...) tudo o que influi ou pode influir sobre a opinião pública, direta ou indiretamente, faz parte dessa estrutura". Dessa maneira, outro aspecto a ser destacado na relação entre os Estudos Culturais e o campo da comunicação refere-se à noção de que os textos midiáticos são portadores de um sentido transparente. Isto é, foi a partir da reflexão sobre hegemonia cultural e o papel das instituições culturais na produção de sentidos e, por conseguinte, na organização das formas de controle e reprodução da ordem social dominante, que se passou a questionar a pretensa transparência dos suportes de comunicação de massa. Na visão de Gramsci, os meios de comunicação

3 Gramsci escreveu sobre a imprensa já que era esta o principal meio de comunicação da sua época. 
são órgãos formadores de consenso, cuja meta é dissipar as expressões de dissenso e fazer reverberar o ideário dominante.

No entanto, reconhecer que os meios se constituem em elementos ativos da estrutura social, onde os produtos culturais exercem importante papel na edificação dos sentidos, não significa alinhar-se à perspectiva adorniana de dominação e alienação. Isso porque as mensagens dos meios de comunicação de massa irão adquirir diferentes significados para os diferentes grupos a partir dos processos de subjetividade, contextualização e formas históricas de cada um. Isso se dá pelo fato de que, outro aspecto a ser considerado refere-se justamente ao deslocamento da centralidade do emissor como único produtor de sentido e significados da mensagem. O novo paradigma traz para o centro da produção de sentidos da mensagem também o receptor, que ao contrário do pressuposto pelos frankfurtianos, possui capacidade crítica para selecionar e reelaborar o conteúdo dos meios massivos. Nesse processo, as mediações sociais são decisivas para determinar como se estabelece o processo comunicacional em cada sociedade. 0 papel ativo do sujeito receptor pode alterar a resultante de todo o processo, uma vez que, a partir das mediações, as pessoas se relacionam com a comunicação de massa, estabelecem negociações simbólicas com base na oferta proposta pelos veículos, assim como na sua visão de mundo, ou seja, seus hábitos e crenças que constituem a sua cultura. Neste processo fica evidente que na cultura popular não existe apenas submissão, mas, também formas de resistência à cultura dominante por meio do deslocamento de significados e/ou ressignificação dos sentidos sociais. 
Neste quesito, os estudos de Martín-Barbero (1997) são essenciais para o campo da comunicação.

Dessa forma, a lógica transmissiva dos estudos da comunicação - abordagem que entende a comunicação como algo unidirecional e unilinear, uma vez que se preocupa com os efeitos de uma mensagem sobre as audiências, numa relação de transmissão de uma informação do emissor para o receptor - é criticada pelos teóricos dos Estudos Culturais. Isso porque na concepção de seus autores, em especial Raymond Williams (1969) e Stuart Hall (2003), tal modelo subentende que toda comunicação é uma comunicação perfeita e transparente. Para Hall (2003, p. 354), "a mensagem é uma estrutura complexa de significados que não é tão simples como se pensa". Portanto, não é possível operar com base num modelo de comunicação determinista, que toma como pressuposto de que o significado da mensagem é fixo, "de que existe uma lógica global que nos permita decifrar o significado ou o sentido ideológico da mensagem contra alguma grade". Para o autor, o sentido possui várias camadas, é sempre multirreferencial.

Assim, a lógica transmissiva e linear - emissor/mensagem/receptor - torna-se inoperante para analisar as relações existentes entre a comunicação, os sujeitos e o tecido social mais amplo, em especial, numa sociedade em que a centralidade do conceito de cultura marca, de forma significativa, a sua organização e, consequentemente, os processos comunicativos, conforme abordado ao longo do texto. Vale ressaltar que, nas teorias contemporâneas da comunicação, a perspectiva interacional constitui-se como a forma mais apropriada para evidenciar a globalidade e complexidade do processo comunicativo. Segundo França, 
A comunicação enquanto interação é uma relação de dois: um e outro estão lá desde o princípio, e não podem ser ignorados (ainda que nosso foco de análise incida mais particularmente sobre a ação de um deles). Não é possível, numa perspectiva interacional, analisar a intervenção de um emissor sem levar em conta o outro a quem ele se dirige e cujas respostas potenciais já atuam com antecedência sobre o seu dizer; não é possível analisar o receptor separado dos estímulos que lhe foram endereçados e que o constituíram como sujeito daquela relação (FRANÇA, 2008, p. 85).

A abordagem comunicacional da interação ressalta que a produção de sentido e de significado se dá em relação. Dessa forma, ao operarmos com a noção de que comunicação é interação, emissor e receptor são mutuamente afetados e não apenas o receptor, que segundo a abordagem adorniana da cultura, atuaria como um sujeito passivo. Ao contrário, a perspectiva que se privilegia na abordagem defendida por este texto valoriza o receptor e suas capacidades de resistir, rebater e apresentar-se como co-autor de mensagem e sentidos. Em vista desses aspectos, a comunicação mostra-se como um campo privilegiado para a reflexão sobre o conceito de cultura e de identidade cultural, uma vez que, dentre outros pontos, "busca-se se ater aos processos humanos e sociais de produção, circulação e interpretação de sentidos, fundados no simbólico e na linguagem" (FRANÇA, 2001, online). Assim, a perspectiva da abordagem comunicacional possibilita trazer elementos e indícios de compreensão do complexo jogo de identificação de discursos, instituição de sentidos e relações, em que sujeitos sociais assumem papéis e constituem lugares de fala no campo de disputa simbólica. 


\section{Referências}

ADORNO, Theodor. Crítica cultural e sociedade. In: COHN, Gabriel.

(Org.) Theodor Adorno. Sociologia. Madri: Taurus, 1971.

ADORNO, Theodor W.; HORKHEIMER, Max. Dialética do esclarecimento: fragmentos filosóficos. Rio de Janeiro: Zahar, 1985.

ADORNO, Theodor W.; HORKHEIMER, Max. Introdução à Controvérsia sobre o Positivismo na Sociologia Alemã. In: Adorno. Consultoria: Paulo Eduardo Arantes. São Paulo: Nova Cultural, 1999 (Coleção Os Pensadores).

MARTIN-BARBERO, Jesús. Dos meios às mediações: comunicação, cultura e hegemonia. Rio de Janeiro: Editora UFRJ, 1997.

FRANÇA, Vera V. Paradigmas da comunicação: conhecer o quê? Ciberlegenda, n. 5, 2001. Disponível em: < http://www.ciberlegenda. uff.br/index.php/revista/article/view/314>. Acesso em: 22/05/2012.

FRANÇA, Vera V. Interações comunicativas: a matriz conceitual de G. H. Mead. In: Primo, Alex et al. (Org.). Comunicação e Interações. Porto Alegre: Sulina, 2008.

GRAMSCl, Antonio. Cadernos do cárcere. 2. ed. Vol. 2. Rio de Janeiro: Civilização Brasileira, 2001.

HALL, Stuart. Da diáspora: identidades e mediações culturais. Belo Horizonte: Editora UFMG, 2003.

HALL, Stuart; CHEN, Kuan-Hsing. A formação de intelectual diaspórico: uma entrevista com Stuart Hall. In: HALL, Stuart. Da diáspora: identidades e mediações culturais. Belo Horizonte: Editora UFMG, 2003. p. 407-434.

HOGGART, Richard. As utilizações da cultura: aspectos da vida da classe trabalhadora, com especiais referenciais a publicações e divertimentos. Tradução de Maria do Carmo Cary. Lisboa: Editorial Presença, 1973a. v. 1.

HOGGART, Richard. As utilizações da cultura: aspectos da vida da classe trabalhadora, com especiais referenciais a publicações e divertimentos. Tradução de Maria do Carmo Cary. Lisboa: Editorial Presença, 1973b. v. 2. 
THOMPSON, Edward P. A formação da classe operária inglesa: a árvore da liberdade. Tradução de Denise Bottmann. 2. ed. Rio de Janeiro: Paz e Terra, 1987a. v. 1.

THOMPSON, Edward P. A formação da classe operária inglesa: a maldição de Adão. Tradução de Renato Busatto Neto e Cláudia Rocha de Almeida. 2. ed. Rio de Janeiro: Paz e Terra, 1987b. v. 2.

THOMPSON, Edward P. A formação da classe operária inglesa: a força dos trabalhadores. Tradução de Denise Bottmann. Rio de Janeiro: Paz e Terra, 1987c. v. 3.

WILLIAMS, Raymond. Cultura e Sociedade. São Paulo: Editora Nacional, 1969.

WILLIAMS, Raymond. Marxismo y Literatura. Barcelona: Ediciones Península, 1977.

WILLIAMS, Raymond. Palavras-chave: um vocabulário de cultura e sociedade. São Paulo: Boitempo, 2007.

\section{Paula Ziviani}

Doutora em Comunicação Social pela Universidade Federal de Minas Gerais (UFMG). Membro do grupo de pesquisa Centro de Convergência de Novas Mídias (CCNM/CNPq/UFMG).

Currículo Lattes: http://buscatextual.cnpq.br/buscatextual/visualizacv.do?id=K4236763A9 